\title{
CARNOSINE AVOIDS THE OXIDATIVE DAMAGE CAUSED BY INTENSE EXERCISE ON RAT SOLEUS MUSCLE
}

\author{
CARNOSINA EVITA O DANO OXIDATIVO CAUSADO PELO EXERCICIO INTENSO NO MÚSCULO \\ SÓLEODERATOS
}

Original Article

ARTIGO ORIGINAL Artículo Original

\section{CARNOSINA EVITA EL DAÑO OXIDATIVO CAUSADO POR EL EJERCICIO INTENSO EN EL MÚSCULO SÓLEODERATONES}

Guilherme Pedrini Bortolatto 1,2 (ID (Physical Education Professional) Hyllana Catarine Dias de Medeiros' 1 (DD (Animal Husbandry Technician)

Marieli Guelfi' (ID

(Biologist)

Marco Aurélio Tavares ${ }^{1}$ (D) (Biologist)

Meiriele Mazzo' ${ }^{1}$ (D) (Pharmacist and Biochemist) Fábio Erminio Mingatto' (DD (Pharmacist and Biochemist)

1. Universidade Estadual Paulista Júlio de Mesquita Filho, Faculdade de Ciências Agrárias e Tecnológicas, Dracena, SP, Brazil.

2. Universidade Estadual Paulista Júlio de Mesquita Filho, Faculdade de Medicina Veterinária, Araçatuba, SP, Brazil.

\section{Correspondence:}

Fábio Erminio Mingatto Rodovia Comandante João Ribeiro de Barros, km 651, Dracena, SP, Brazil. 17900-000. fabio.mingatto@unesp.br

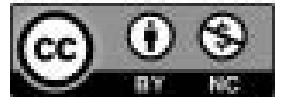

\begin{abstract}
Introduction: Intense physical exercise affects the balance between the production of reactive oxygen species and antioxidant defense in the muscle. Carnosine is a cytoplasmic dipeptide composed of the amino acids $\beta$-alanine and histidine. Objective: This study aimed to evaluate the effect of carnosine and its precursor $\beta$-alanine on oxidative damage caused by intense physical exercise in the soleus muscle of rats. Methods: Male Wistar rats weighing between 200 and $240 \mathrm{~g}$ were divided into four groups: control, exercise, exercise + $\beta$-alanine and exercise + carnosine. The animals from the groups that underwent the exercise ran on a treadmill for 60 minutes at $25 \mathrm{~m} /$ minute. Factors related to muscle damage and oxidative stress were assessed in soleus muscle homogenate and blood serum. Results: The exercise promoted muscle damage, as observed through increased serum activity of enzymes aspartate aminotransferase and creatine kinase. It also induced oxidative stress in soleus muscle, as seen by the increased activity of the enzymes glutathione peroxidase and glutathione reductase, decreased concentration of reduced glutathione, and increased concentration of malondialdehyde, an indicator of lipid peroxidation. Carnosine kept the creatine kinase, glutathione peroxidase and glutathione reductase enzyme activity values, and the concentration of reduced glutathione and malondialdehyde, close to those of the control group. Conclusion: The results indicate that pretreatment with carnosine protected the rat soleus muscle against oxidative damage and consequent injury caused by intense physical exercise. Level of evidence Il; Therapeutic studies-Investigating the treatment results.
\end{abstract}

Keywords: Antioxidants; Oxidative stress; Free radicals; Exercise test.

\section{RESUMO}

Introdução: O exercício físico intenso afeta o equilibrio entre a produção de espécies reativas de oxigênio e a defesa antioxidante no músculo. A carnosina é um dipeptídeo citoplasmático composto pelos aminoácidos $\beta$-alanina e histidina. Objetivo: O presente trabalho teve como objetivo avaliar o efeito da carnosina e do seu precursor $\beta$-alanina nos danos oxidativos causados pelo exercício físico intenso no músculo sóleo de ratos. Métodos: Ratos Wistar machos pesando entre 200 e $240 \mathrm{~g}$ foram divididos em quatro grupos: controle, exercício, exercício + $\beta$-alanina e exercício + carnosina. Os animais dos grupos submetidos ao exercício correram em esteira por 60 minutos a $25 \mathrm{~m} /$ minuto. Fatores relacionados ao dano muscular e estresse oxidativo foram avaliados no soro sanguíneo e no homogenato do músculo sóleo. Resultados: O exercício promoveu lesão muscular conforme observado através do aumento da atividade sérica das enzimas aspartato aminotransferase e creatina quinase. Além disso, induziu o estresse oxidativo no músculo sóleo, observado pelo aumento da atividade das enzimas glutationa peroxidase e glutationa redutase, diminuição da concentração de glutationa reduzida e aumento na concentração de malondialdeído, um indicador de lipoperoxidação. A carnosina manteve os valores da atividade das enzimas creatina quinase, glutationa peroxidase e glutationa redutase, além da concentração de glutationa reduzida e malondialdeído próximos aos do grupo controle. Conclusão: Os resultados indicam que o tratamento prévio com carnosina protegeu o músculo sóleo de ratos contra os danos oxidativos e a consequente lesão provocada pelo exercício físico intenso. Nível de evidência II; Estudos terapêuticos-investigação dos resultados do tratamento.

Descritores: Antioxidantes; Estresse oxidativo; Radicais livres; Teste de esforço.

\section{RESUMEN}

Introducción: El ejercicio físico intenso afecta al equilibrio entre la producción de especies reactivas de oxígeno y la defensa antioxidante en el músculo. La carnosina es un dipéptido citoplasmático compuesto por los aminoácidos B-alanina e histidina. Objetivo: El presente trabajo tuvo como objetivo evaluar el efecto de la carnosina y de su precursor B-alanina en los daños oxidativos causados por el ejercicio físico intenso en el músculo sóleo de ratones. Métodos: Ratones Wistar machos pesando entre 200 y 240 g fueron divididos en cuatro grupos: control, ejercicio, ejercicio + $\beta$-alanina y ejercicio + carnosina. Los animales de los grupos sometidos al ejercicio corrieron en cinta durante 60 minutos a $25 \mathrm{~m} /$ minuto. Se evaluaron los factores relacionados al daño muscular y al estrés oxidativo en el suero sanguíneo y el homogenato del músculo sóleo. Resultados: El ejercicio promovió lesión muscular, conforme fuera 
observado a través del aumento de la actividad sérica de las enzimas aspartato aminotransferasa y creatina quinasa. Además, indujo al estrés oxidativo en el músculo sóleo, observado por el aumento de la actividad de las enzimas glutatión peroxidasa y glutatión reductasa, disminución de la concentración de glutatión reducido y aumento de la concentración de malondialdehido, un indicador de lipoperoxidación. La carnosina mantuvo los valores de actividad de las enzimas creatina quinasa, glutatión peroxidasa y glutatión reductasa, además de la concentración de glutatión reducido y malondialdehído cercanos a los del grupo de control. Conclusión: Los resultados indican que el tratamiento previo con carnosina protegió al músculo sóleo de ratones contra los daños oxidativos y la consiguiente lesión causada por el ejercicio físico intenso. Nivel de evidencia Il; Estudios terapéuticos-Investigación de los resultados del tratamiento.

Descriptores: Antioxidantes; Estrés oxidativo; Radicales libres; Prueba de esfuerzo.

\section{INTRODUCTION}

As a result of aerobic metabolism, the human body continually produces free radicals known as reactive oxygen species (ROS). Oxidative stress is defined as the change in the state of equilibrium between ROS production and its removal by cellular antioxidant systems. The continuous production of free radicals during metabolic processes makes it important to have many antioxidant defense mechanisms that limit the intracellular levels of reactive oxygen species and prevent the induction of damage.' Increased oxygen uptake through the activation of different metabolic pathways during or after exercise results in increased ROS and may cause damage to skeletal muscle. ${ }^{2}$

Analysis of plasma enzyme concentrations, such as creatine kinase (CK) and aspartate aminotransferase (AST), are indirect indicators of structural damage to skeletal muscle. ${ }^{3}$ The serum concentration of these enzymes correlates to the functional state of muscle tissue, and varies under both pathological and physiological conditions. ${ }^{4}$

Glutathione is a tripeptide (L-y-glutamyl-L-cysteinyl-glycine) present in the body in its reduced (GSH) and oxidized (GSSG) forms, acting directly or indirectly in many important biological processes, including protein synthesis, metabolism, and cell protection. Reduced glutathione (GSH) can be considered one of the most important agents in the cell's antioxidant defense system, protecting the cell against injury resulting from exposure to oxidizing agents. ${ }^{5}$

Glutathione peroxidase (GPx) is an enzyme in the cellular antioxidant system that eliminates hydrogen peroxide. ${ }^{6}$ Another enzyme that acts in conjunction with GPx is glutathione reductase (GR). This enzyme does not act directly in the removal of radical species, but is responsible for the regeneration of GSSG to GSH in the presence of nicotinamide adenine dinucleotide phosphate (NADPH), aiming to prevent glutathione metabolic cycle arrest. ${ }^{5}$

Lipid peroxidation products, such as malondialdehyde (MDA), can be used as indicators of free radical action in the body? ${ }^{7}$ MDA has cytotoxic and genotoxic action, and can be found at elevated levels in some pathologies associated with oxidative stress. ${ }^{8}$

Carnosine (N-b-alanyl-L-histidine) is a multifunctional pluripotent dipeptide found in a variety of tissues, and at particularly high concentrations in the brain and muscles. ${ }^{9}$ Several studies have addressed its properties as an antioxidant, immunomodulator and neuroprotective agent. ${ }^{10}$

$\beta$-alanine is a beta amino acid that, together with histidine, forms carnosine. Some reports have indicated that supplementation with this precursor would have advantages over carnosine ingestion, claiming that the latter is degraded in the digestive tract (stomach and intestine) in its two constituents which, despite being used once again in the formation of carnosine itself, suffer a loss in their usability throughout this process, implying that supplementation with $\beta$-alanine rather than carnosine is more worthwhile from the physiological and financial point of view. ${ }^{11}$ In this work we analyzed the effect of carnosine and $\beta$-alanine supplementation on oxidative damage produced by intense physical exercise in rat soleus muscle.

\section{MATERIALS AND METHODS}

The 100\% pure $\beta$-alanine (146064) and carnosine (C9625) 100\% were acquired from the company Sigma-Aldrich Brasil Ltda (São Paulo, SP, Brazil).

Thirty-two male Wistar rats weighing between 200 and $240 \mathrm{~g}$ were used. Four animals were housed in each box and the boxes were stored at a controlled temperature of approximately $22^{\circ} \mathrm{C}$, with the rats receiving food and water ad libitum, using a diet standardized for laboratory animals (Nuvilab® ${ }^{\oplus}$, Colombo, PR, Brazil).

The animals were divided into four groups containing eight animals each. They all underwent a three-week training protocol on the motorized treadmill designed for rats (Single Rodent Motorized Treadmill, AVS Projects, Ribeirão Preto, SP, Brazil), and the animals in groups 2, 3 and 4 underwent intense exercise on the treadmill, running for 60 minutes at 25 $\mathrm{m} / \mathrm{min}$. The animals from group 3 received $\beta$-alanine ( $1 \mathrm{mg} / \mathrm{kg}$ body mass) dissolved in water (oral gavage) on the last 15 days of the protocol, and then underwent intense exercise, while the animals in group 4 received carnosine (1 mg/kg body mass) dissolved in water (oral gavage) on the last 15 days of the protocol and then underwent intense exercise.

In the training protocol, all animals were accustomed to running on the motorized treadmill starting at $8 \mathrm{~m} / \mathrm{min}$ for 10 min on three days a week. Over a three-week period, exercise intensity was gradually increased to $25 \mathrm{~m} / \mathrm{min}$ while the $10 \mathrm{~min}$ duration was maintained. On the day of the experiment, the animals in groups 2, 3 and 4 performed the intense exercise on the treadmill running for $60 \mathrm{~min}$ at $25 \mathrm{~m} / \mathrm{min}$.

Twenty-four hours after the intense physical exercise, the rats were euthanized by decapitation to collect blood and soleus muscle.

The Animal Experimentation Institutional Review Board (CEUA) of the Unesp Dracena Campus has certified that procedures using animals are in accordance with the standards set out in the Guide for the Care and Use of Laboratory Animals and in the Ethical Principles in Animal Experimentation of the Colégio Brasileiro de Experimentação Animal (Brazilian College of Animal Experimentation) (Protocol CEUA 19/2014).

The animals' blood was collected individually in $15 \mathrm{~mL}$ tubes and kept at room temperature for 15 minutes for coagulation. Serum was separated by centrifugation (Eppendorf Centrifuge, model 5804-R, Hamburg, Germany) at a speed of $3000 \mathrm{rpm}$ for $15 \mathrm{~min}$. The activities of the enzymes indicating muscle damage (AST and CK) were measured in a spectrophotometer (model DU800, Beckman Coulter, USA), using commercial enzyme dosing kits (K010-1 and K048-6, Bioclin, Belo Horizonte, Brazil) according to the manufacturer's instructions.

The soleus muscle was removed and placed in approximately $50 \mathrm{~mL}$ of medium containing $250 \mathrm{mM}$ sucrose, $1 \mathrm{mM}$ EGTA and $10 \mathrm{mM}$ HEPES with pH 7.2 at $4^{\circ} \mathrm{C}$, where it was finely chopped and taken to a PotterElvehjem type homogenizer and homogenized three times for $15 \mathrm{~s}$ at 1 -min intervals. The homogenate was centrifuged at $750 \mathrm{~g}$ for $3 \mathrm{~min}$ 
at $4^{\circ} \mathrm{C}$ (Eppendorf Centrifuge, model 5804-R, Hamburg, Germany) to separate cell membranes, and the supernatant was used in the analyses.

Protein determination in the homogenate was performed using the biuret method with bovine serum albumin as standard.

GPx enzyme activity was determined in a $4 \mathrm{~mL}$ quartz cuvette in which $1 \mathrm{~mL}$ of $0.1 \mathrm{mM}$ sodium phosphate buffer (pH 7.6) containing 0.5 mM EDTA, $10 \mu \mathrm{L}$ 10\% triton X-100, soleus muscle homogenate (1 mg protein), $5 \mu \mathrm{L} 100 \mathrm{mM}$ GSH and $20 \mu \mathrm{l} 10 \mathrm{mM}$ NADPH were added. After 1 minute of incubation, $10 \mu \mathrm{L}$ of $25 \mathrm{mM} \mathrm{H}_{2} \mathrm{O}_{2}$ was added and the change in absorbance was determined at a wavelength of $340 \mathrm{~nm}$ in a Beckman-Coulter DU-800 spectrophotometer (Fullerton, CA, USA). Data were expressed in $\mathrm{U} / \mathrm{mg}$ of protein.

GR enzyme activity was determined in a $4 \mathrm{~mL}$ quartz cuvette to which $1 \mathrm{~mL}$ of $0.1 \mathrm{mM}$ sodium phosphate buffer ( $\mathrm{pH}$ 7.6), containing 0.5 mM EDTA, $10 \mu \mathrm{L} 10 \%$ triton X-100, soleus muscle homogenate (1 $\mathrm{mg}$ protein) and $10 \mu \mathrm{l} 100 \mathrm{mM}$ GSSG were added. Then the specimens were incubated at $30^{\circ} \mathrm{C}$ for 5 minutes. Immediately afterwards, 10 $\mu \mathrm{l}$ of $10 \mathrm{mM}$ NADPH was added and the change in absorbance was determined at the wavelength of $340 \mathrm{~nm}$ in a Beckman-Coulter DU800 spectrophotometer (Fullerton, CA, USA). Data were expressed in $\mathrm{U} / \mathrm{mg}$ of protein.

GSH concentration was determined in a $2 \mathrm{~mL}$ tube, in which the homogenate (1 mg of protein), medium containing $125 \mathrm{mM}$ sucrose, $65 \mathrm{mM} \mathrm{KCl}$ and $10 \mathrm{mM} \mathrm{HEPES-KOH} \mathrm{(pH} \mathrm{7.4)} \mathrm{were} \mathrm{added} \mathrm{to}$ complete $1 \mathrm{~mL}$. After brief homogenization, $500 \mu \mathrm{l}$ 13\% trichloroacetic acid were added. The mixture was stirred and centrifuged at $9000 \mathrm{~g}$ for $3 \mathrm{~min}$. To measure GSH, $1800 \mu \mathrm{L}$ of buffer containing $0.1 \mathrm{M}$ $\mathrm{NaH}_{2} \mathrm{PO}_{4}(\mathrm{pH}$ 8.0) with $5 \mathrm{mM}$ EDTA, $100 \mu \mathrm{L}$ of supernatant obtained from centrifugation and $100 \mu \mathrm{L}$ of OPA (o-phthalaldehyde) $1 \mathrm{mg} / \mathrm{mL}$ were added in $5 \mathrm{~mL}$ test tubes. Then the tubes were shaken and kept for 15 minutes in the dark at room temperature. Reading was performed in an RFPC 5301 spectrofluorometer (Shimadzu, Japan) with a wavelength of 350 and $420 \mathrm{~nm}$ for emission and excitation, respectively, with opening of slot 3 in both cases. GSH concentration was estimated using a standard curve.

Membrane lipid peroxidation was determined using the TBARS (thiobarbituric acid reactive substances) method. For this purpose, the soleus muscle homogenate (5 $\mathrm{mg}$ protein) was placed in a test tube and $0.2 \mathrm{~mL}$ SDS (8.1\%), $1.5 \mathrm{~mL}$ acetic acid (20\%), and $1.5 \mathrm{mLTBA}$ $(0.67 \%$ aqueous solution) were added. The volume was topped up to $4 \mathrm{~mL}$ with deionized water (milli-Q), and the mixture placed in a water bath at $95^{\circ} \mathrm{C}$ for $60 \mathrm{~min}$. After the incubation period the tubes were removed and cooled in an ice bath, then $1 \mathrm{ml}$ of milli-Q water was added and the MDA-TBA complex was extracted with $5 \mathrm{~mL}$-butanol. After this the tubes were centrifuged at $2000 \mathrm{~g}$ for 10 minutes, the organic part was collected and the absorbance measured at $535 \mathrm{~nm}$. Malondialdehyde (MDA) concentration was determined using the molar extinction coefficient of $1.56 \times 10^{5} \mathrm{M}^{-1} \mathrm{~cm}^{-1}$. Data were expressed in $\mathrm{nmol} / \mathrm{mg}$ of protein.

\section{Statistical analysis}

Statistical significance of the experimental data was determined using one-way ANOVA, and multiple comparison of means was performed using the Tukey test. The significance level adopted was 5\% ( $p<0.05)$, and the analyses were performed using the GraphPadPrism program, version 4.0 for Windows, GraphPad Software (San Diego, CA, USA 03/04/2003).

\section{RESULTS}

Physical exercise (G2) produced an increase in serum activity of enzymes AST and CK (Figures 1A and 1B, respectively) in comparison to the control group (G1), which were used as a parameter of muscle injury. The results obtained for groups 3 and 4 show that only carnosine treatment was able to protect the soleus muscle against damage caused by physical exercise, as observed by the decrease in CK enzyme release (Figure 1B).

Analysis of the activity of GR and GPX enzymes in soleus muscle homogenate (Figures $2 \mathrm{~A}$ and $2 \mathrm{~B}$, respectively) showed an increase in muscle activity of these enzymes caused by physical exercise (G2) as compared to the control group (G1). Only the treatment of animals with carnosine (G4) promoted a decrease in enzyme activity as compared to the physical exercise group (G2).

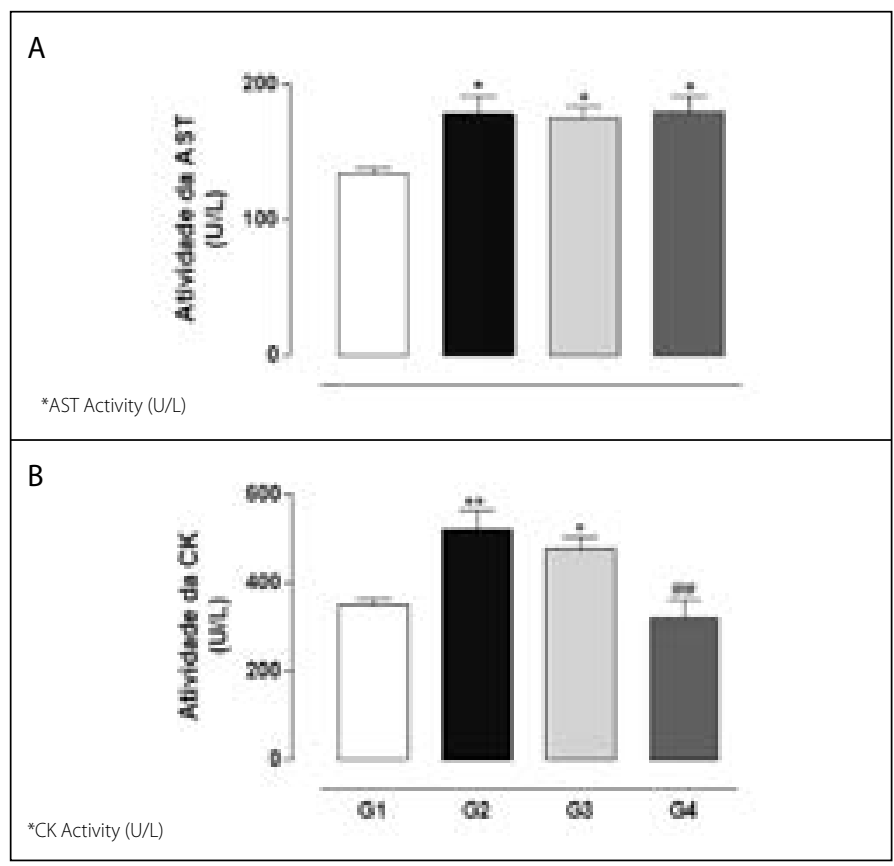

Figure 1. Serum activity of the enzymes aspartate aminotransferase (AST) (A) and creatine kinase $(C K)(B)$ in rat blood serum. Results represent the mean \pm standard error of the mean of eight animals per group. G1 = control; $\mathrm{G} 2=$ physical exercise; $\mathrm{G} 3$ $=\beta$-alanine + physical exercise; $G 4=$ carnosine + physical exercise. $\left({ }^{*},{ }^{* *}\right)$ differs from G1 ( $p<0.05$ and $p<0.01$, respectively); (\#\#) differs from $G 2(p<0.01)$.

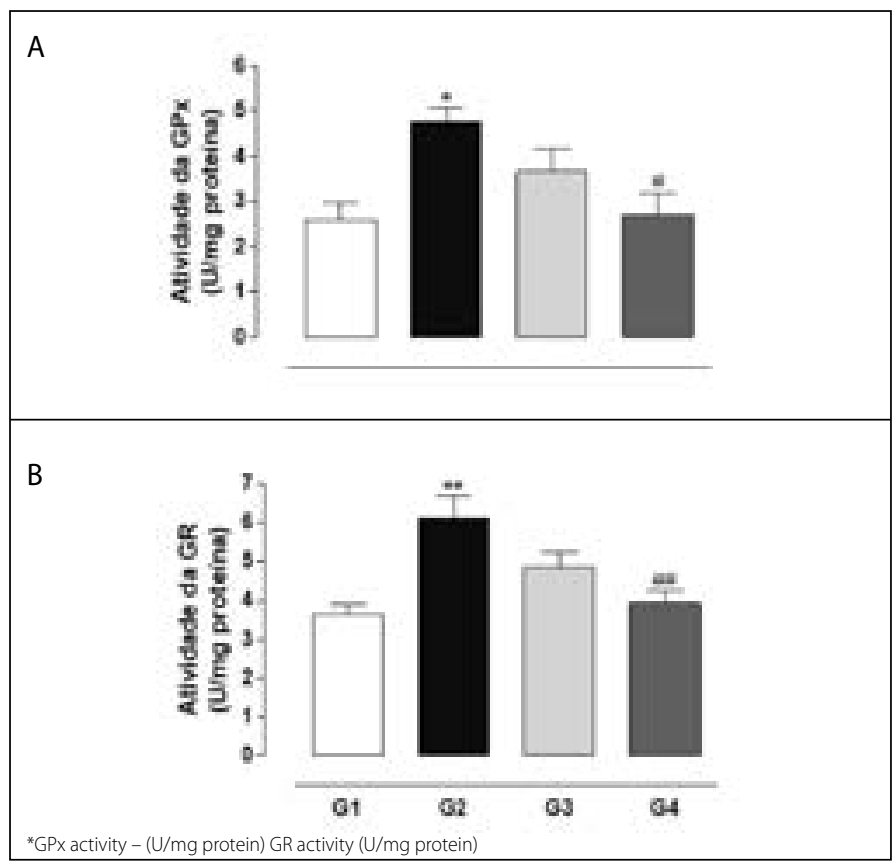

Figure 2. Activity of enzymes glutathione peroxidase (GPx) (A) and glutathione reductase (GR) (B) in rat soleus muscle homogenate. Results represent the mean \pm standard error of the mean of eight animals per group. $\mathrm{G} 1$ = control; $\mathrm{G} 2$ = physical exercise; $\mathrm{G} 3=\beta$-alanine + physical exercise; G4 = carnosine + physical exercise. $\left(^{*}{ }^{* *}\right)$ differs from G1 $(p<0.05$ and $p<0.01$, respectively); (\#, \#\#) differs from $G 2$ ( $p<0.05$ and $p<0.01$, respectively). 
Physical exercise (G2) produced a decrease in GSH concentration in the soleus muscle as compared to the control group (G1), as shown in Figure 3. Treatment of the animals with carnosine (G4) made it possible to keep the GSH concentration close to that of the control group (G1).

Figure 4 demonstrates that physical exercise (G2) stimulated the increase in MDA production in comparison to the control group (G1), indicating that there was oxidation of membrane lipids. Carnosine (G4) treatment protected the muscle against oxidative damage caused by physical exercise.

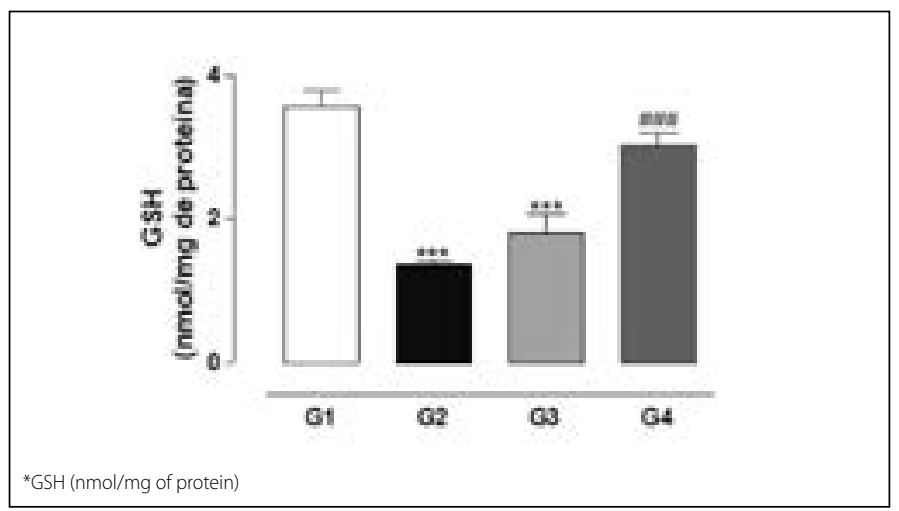

Figure 3. Reduced glutathione (GSH) concentration in rat soleus muscle homogenate. Results represent the mean \pm standard error of the mean of eight animals per group. $\mathrm{G} 1$ = control; $\mathrm{G} 2$ = physical exercise; $\mathrm{G} 3=\beta$-alanine + physical exercise; $\mathrm{G} 4=$ carnosine + physical exercise. $\left(^{* *}\right)$ differs from $\mathrm{G} 1(\mathrm{p}<0.001)$; (\#\#\#) differs from $G 2(p<0.001)$.

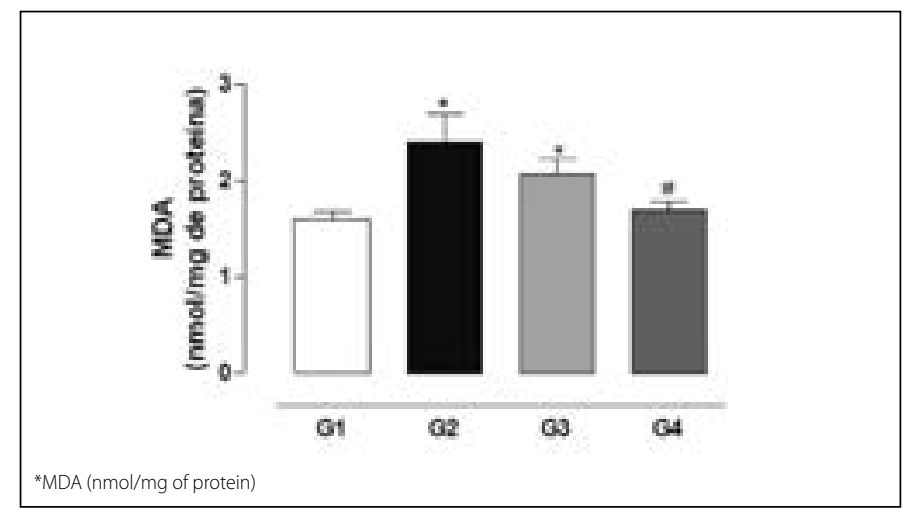

Figure 4. Malondialdehyde (MDA) concentration in rat soleus muscle homogenate. Results represent the mean \pm standard error of the mean of eight animals per group. $\mathrm{G} 1$ = control; $\mathrm{G} 2$ = physical exercise; $\mathrm{G} 3=\beta$-alanine + physical exercise; $\mathrm{G} 4=$ carnosine + physical exercise. $\left(^{*}\right)$ differs from $G 1(p<0.05)$; (\#) differs from $G 2(p<0.05)$.

\section{DISCUSSION}

The results of this study showed that the intense physical exercise applied to the animals brought about an increase in the serum activity of enzymes AST and CK in comparison to the control group, indicating the occurrence of muscle injury. Treatment of animals with carnosine protected the soleus muscle from damage caused by physical exercise, as corroborated by the decrease in the release of CK enzyme.

Regarding the analysis of GPx and GR enzyme activity in soleus muscle homogenate of the rats that underwent exercise in this study, there was an increase in the muscle activity of these enzymes when compared with the control group. These results are consistent with those obtained in previous studies that have shown that, to protect tissue against potential damage caused by ROS, antioxidant enzymes such as SOD, catalase (CAT), GPx and GR appear to respond in an adaptive manner by elevating their activity in the tissues and organs of individuals in training. ${ }^{12,13}$ The previous treatment of animals with carnosine showed a reduction in the activity of these enzymes in muscle homogenate, indicating an antioxidant action. Vieira Junior et al., ${ }_{1}^{14}$ found differences in GPx enzyme activity between the two groups evaluated, with higher mean values in the group that had swimming training compared to the sedentary group. In another study, the authors only identified glutathione peroxidase activity difference at certain training intensities. ${ }^{15}$

The effects of aerobic exercise do not just involve the activity of enzymatic antioxidants, since effects on non-enzymatic antioxidants can also be observed. In this context, physical exercise brought about a decrease in GSH concentration in the rat soleus muscle compared to the control group, while carnosine used to treat animals allowed the maintenance of GSH concentration. Some studies have shown that glutathione (GSH), the main non-enzymatic cellular antioxidant, or the relationship between GSH and its oxidized form (GSSG), can be reduced during physical exercise. ${ }^{16,17}$

Physical exercise stimulated the increase in MDA production in comparison to the control group, indicating that there was membrane lipid peroxidation. Carnosine once again protected the muscle against oxidative damage caused by intense exercise. According to Alessio and Goldfarb, ${ }^{18}$ there was a slight increase in lipid peroxidation in both liver and skeletal muscle of rats following submaximal treadmill running. Boldyrevet al. ${ }^{19}$ demonstrated that in the presence of carnosine there was a decrease in concentrations of products strictly related to lipid peroxidation in skeletal muscle.

The antioxidant effects of carnosine found in this study are in accordance with reports published in the literature demonstrating a scavenger activity (ability to interact and sequester free radicals, forming less reactive compounds) of the radicals superoxide and hydroxyl by carnosine, or their metal chelating action. ${ }^{20} \mathrm{~A}$ recent study, in which kayak and canoe athletes received supplementation with $4 \mathrm{~g}$ /day carnosine for 14 days, showed a significant decrease in the production of oxidative stress markers in the blood. ${ }^{21}$

Although some studies suggest that orally ingested carnosine is almost immediately cleaved into $\beta$-alanine and L-histidine, even before it reaches the bloodstream, ${ }^{22}$ other authors have shown that carnosine hydrolysis in the small intestine is only partial, ${ }_{1}^{23,24}$ and that therefore part of the orally ingested carnosine remains intact in the circulation for a few hours and is available for uptake by peripheral tissues. ${ }^{25}$ In this regard, although $\beta$-alanine supplementation has been pointed out as the most efficient way to increase muscle carnosine, ${ }^{16}$ studies have shown that carnosine supplementation also increased the concentration of this dipeptide in rat skeletal muscle. ${ }^{26,27}$

Carnosine has been tested in various pathologies and physiological states related to free radical production, showing evidence of its prospective use as an antioxidant and tissue protector against various adverse factors that induce the development of oxidative stress. ${ }^{28}$

In this particular study carnosine supplementation was more effective than $\beta$-alanine, and these results are consistent with several studies showing that ingestion of $\beta$-alanine alone had no antioxidant effect as observed for dipeptide. ${ }^{29,30}$

\section{CONCLUSION}

Carnosine was able to prevent oxidative damage produced by intense physical exercise in rat soleus muscle. Thus, we suggest the use of carnosine in the form of a supplement in athletes subject to muscle injuries caused by exercise.

All authors declare no potential conflict of interest related to this article 
AUTHORS' CONTRIBUTIONS: Each author made significant individual contributions to this manuscript. GPB, HCDM, MG, MAT and MM: design of the experiments, data collection, data analysis, writing; FEM: writing, statistical analysis, intellectual concept and creation of the entire research project. All authors reviewed and approved the final version of the manuscript.

\section{REFERENCES}

1. Schneider DC, De Oliveira AR. Radicais livres de oxigênio e exercício: mecanismos de formação e adaptação ao treinamento físico. Rev Bras Med Esporte. 2004;10(4):308-12.

2. Souza JrTP, De Oliveira RP, Pereira B. Exercício físico e estresse oxidativo: efeitos do exercício físico intenso sobre a quimiluminescência urinária e malondialdeído plasmático. Rev Bras Med Esporte. 2005;11(1):91-6

3. van de Vyver M, Myburch KH. Cytokine and satellite cell responses to muscle damage: interpretation and possible confounding factors in human studies. J Muscle Res Cell Motil. 2012;33(3-4):177-85.

4. Hammouda O, Chahed H, Chtourou H, Ferchichi S, Miled A, Souissi N. Morning-to-evening difference of biomarkers of muscle injury and antioxidant status in young trained soccer players. Biol Rhythm Res. 2012:43(4):431-8.

5. Meister A, Anderson ME. Glutathione. Annu Rev Biochem. 1983;52:711-60.

6. Halliwell B, Gutteridge JM. Free radicals in biology and medicine. 4th edition. Oxford: Clarendon; 2007.

7. Özguner MF, Delibas N, Tahan V, Koyu A, Koylu H. Effects of industrial noise on the blood levels of superoxide dismutase, glutathione peroxidase and malondialdehyde. Eas J Med. 1999;4(1):13-5.

8. Steghens JP, van Kappel AL, Denis I, Collombel C. Diaminonaphtalene, a new highly specific reagent for HPLC-UV measurement of total and free malondialdehyde in human plasma or serum. Free Radical Bio Med. 2001;31(2):242-9.

9. De Marchis S, Melcangi RC, Modena C, Cavaretta I, Peretto P, Agresti C, et al. Identification of the glial cell types containing carnosine-related peptides in the rat brain. Neurosci Lett. 1997;237(1):37-40.

10. Boldyrev AA, Aldini G, Derawe W. Physiology and pathophysiology of carnosine. Physiol Rev. 2013;93(4):1803-45.

11. Hill CA, Harris RC, Kim HJ, Harris BD, Sale C, Boobis LH, et al. Influence of beta-alanine supplementation on skeletal muscle carnosine concentrations and high intensity cycling capacity. Amino Acids. 2007;32(2):225-33.

12. Pereira B, Costa Rosa LF, Bechara EJ, Curi R. Antioxidant enzymes in the lymphoid organs and macrophages of rats trained to moderate exercise. Ciência e Cultura. 1996;48:43-6.

13. Reddy Avula CP, Fernandes G. Modulation of antioxidant and lipid peroxidation in salivary gland and other tissues in mice by moderate treadmill exercise. Aging (Milano). 1999;11(4):246-52.

14. Vieira Junior RC, Silva CM, Araújo MB, Garcia A, Voltarelli VA, Reis Filho AD, et al. Treinamento aeróbio de natação aumenta a atividade de enzimas antioxidantes e o conteúdo de glicogênio no músculo esquelético de ratos. Rev Bras Med Esporte.2013;19(3):204-8.

15. Schneider CD, Barp J, Ribeiro JL, Belló-klein A, Oliviera AR. Oxidative stress after three different intensities of running. Can J Appl Physiol. 2005;30(6):723-34.
16. Ji LL, Fu R. Responses of glutathione system and antioxidant enzymes to exhaustive exercise and hydroperoxide. J Appl Physiol (1985). 1992;72(2):549-54.

17. Tessier F, Margaritis I, Richard MJ, Moynot C, Marconnet P. Selenium and training effects on the glutathione system and aerobic performance. Med Sci Sports Exerc. 1995;27(3):390-6.

18. Alessio HM, Goldfarb AH. Lipid peroxidation and scavenger enzymes during exercise: adaptative response to training. J Appl Physiol (1985). 1988;64(4):1333-6.

19. Boldyrev AA, Dupin AM, Pindel EV, Severin SE. Antioxidative properties of histidine-containing dipeptides from skeletal muscles of vertebrates. Comp Biochem Phys B. 1988;89(2):245-50

20. Kohen R, Yamamoto Y, Cundy KC, Ames BN. Antioxidant activity of carnosine, homocarnosine, and anserine present in muscle and brain. P Natl Acad Sci USA. 1988;85(9):3175-9.

21. Slowinska-Lisowska M, Zembron-Lancy A, Rynkiewicz M, Rynkiewicz M, Rynkiewickz T, Kopec W. Influence of ${ }_{-}$-carnosine on pro-antioxidant status in elite kayakers and canoeists. Acta Physiol Hung. 2014;101(4):461-70

22. Asatoor, AM, Bandoh JK, Lant AF, Milne MD, Navab F. Intestinal absorption of carnosine and its constituent amino acids in man. Gut. 1970;11(3):250-4

23. Hama T, Tamaki N, Miyamoto F, Kita M, Tsunemori F. Intestinal absorption of beta-alanine, anserine and carnosine in rats. J Nutr Sci Vitaminol (Tokyo). 1976;22(2):147-57.

24. Dunnett M, Harris RC, Dunnett CE, Harris PA. Plasma carnosine concentration: diurnal variation and effects of age, exercise and muscle damage. Equine Vet J. 2002;34(Suppl):283-7.

25. Painelli VS, Freitas P, Gualano B, Artioli GG. Metabolismo de carnosina, suplementação de $\beta$-alanina e desempenho físico: atualização - Parte I. Rev Bras Nutr Esportiva. 2015;9(52):361-78.

26. Maynard LM, Boissonneault GA, Chow CK, Bruckner GG. High levels of dietary carnosine are associated with increased concentrations of carnosine and histidine in rat soleus muscle. J Nutr. 2001;131 (2):287-90

27. Yi HC, Kim MY, Choi CS, Kim YN, Han CK, Lee BH. Effects of carnosine supplementation on carnosine concentrations in muscles and blood biochemical indices of rats. Korean J Food Sci An. 2012;32(5):584-90.

28. Prokopieva VD, Yarygina EG, Bokhan NA, Ivanova SA. Use of carnosine for oxidative stress reduction in different pathologies. Oxid Med Cell Longev. 2016;2016:2939087.

29. Aruoma OI, Laughton MJ, Halliwell B. Carnosine, homocarnosine and anserine: could they act as antioxidants in vivo? Biochem J. 1989;264:863-9

30. Smith AE, Stout JR, Kendall KL, Fukuda DH, Cramer JT. Exercise-induced oxidative stress: the effects of $\beta$-alanine supplementation in women. Amino Acids. 2012;43(1):77-90. 